\title{
Young people confronting the challenge of reading and interpreting a digital world
}

\author{
Jóvenes enfrentando el reto de leer e interpretar un mundo digital
}

\author{
Jordi Castellví Mata \\ Universidad Internacional de la Rioja \\ Breogán Tosar Bacarizo \\ Antoni Santisteban Fernández \\ Universitat Autònoma de Barcelona
}

\begin{abstract}
Critical citizenship education must consider the global and digital context in which we live. Digital media and global processes have a decisive influence on people's daily lives. However, digital literacy programs rarely go beyond teaching technological skills. Similarly, critical thinking approaches to education focus on developing cognitive skills, omitting the weight of values and emotions in decision making. This research analyses Spanish secondary school students' narratives and reflections about two publications on Twitter that present biased information to encourage undemocratic attitudes. The results show that most students are far from being critical of the information they read on the internet, and they easily fall into the trap of defending undemocratic discourses.
\end{abstract}

Keywords: Undemocratic discourses; Critical digital literacy; Critical thinking; Democratic values

\section{Resumen}

La educación para una ciudadanía crítica debe considerar el contexto global y digital en el que vivimos. Los medios digitales y los procesos globales repercuten decisivamente en la vida diaria de la ciudadanía. Sin embargo, los programas de alfabetización digital rara vez van más allá de la enseñanza de habilidades tecnológicas. De forma similar, las aproximaciones a la formación del pensamiento crítico se centran en el desarrollo de habilidades cognitivas, omitiendo el peso de los valores y las emociones en la toma de decisiones de la ciudadanía. Esta investigación analiza las narraciones y reflexiones de estudiantes de educación secundaria españoles sobre dos publicaciones en Twitter que presentan información sesgada para promover actitudes no democráticas. Los resultados muestran que la mayoría de los estudiantes están lejos de ser críticos con la información que leen en internet, y fácilmente caen en la defensa de discursos no democráticos.

Palabras clave: Discursos no democráticos;

Literacidad crítica digital; Pensamiento crítico;

Valores democráticos 


\section{INTRODUCTION}

Freire bequeathed the idea that learning to read is more than a mere mechanical process, and that the way it is taught has key implications for developing critical thinking (Freire \& Macedo, 2004). These authors argue that the idea of reading the word is necessarily related to the idea of reading the world. However, neither the world nor the words of the late 1980's were the same as the ones we face today. Digital media has changed the way we work, gather information and participate politically. Knowledge construction, social relations, economics, and many other areas of public and private life are influenced in one way or another by the digital context in which we live. Hence, we consider that we can no longer educate a critical society without considering this global and digital context.

The influences of social and digital media are especially relevant among young people. Websites like Wikipedia and social networks are their main source of information (Blikstad-Balas, 2015; Castellví, 2019) and therefore have an impact on their general knowledge and on the construction of certain values. Nevertheless, we know that the biggest influence is still the family (Castellví, 2019; Schulz et al., 2016). Moreover, new generations typically show disaffection for traditional forms of social participation, that is to say, they are less disposed towards future public participation through political parties (Schulz et al., 2016) and instead prefer to participate in accordance with the idea of thick or maximal citizenship (Kennedy, 2019), which includes non-institutionalized forms of participation, such as political participation via social media (Kahne et al., 2016). In fact, a study by Havas Group (2011) finds that $60 \%$ of young people consider digital media to be the new power of youth, and $70 \%$ consider it to be a driving force for social change.

This optimistic view of new technologies contrasts with Debord's (2015) ideas. This author predicted in the 1960's that we would enter an era in which the power of screens would rule over public life, and where spectacle would prevail over information. This thesis is correct for various scholars (e.g Eco, 1998; Kellner, 2005; Ross, 2013; Santisteban et al., 2020), who do not consider that we live in the information society, but in the spectacle society. Fake news and post-truth politics are relatively recent phenomena and are strongly related to the proliferation of the social and digital media, and the power of corporations, political parties and other social agents to exploit them for their own benefit in morally questionable ways is a reality. These messages influence the whole population, but their effect is stronger on the most connected part of it: young people. 
Research on global and digital citizenship has focused on the development of a population that crosses borders and national identities (e.g. Andreotti, 2006; Davies, 2006; Estellés \& Fischman, 2020; González-Valencia et al., 2020; Oxley $\&$ Morris, 2013). However, the relations between citizenship education and digital environments has been understudied, and mainly form the prism of participation, activism and digital citizenship (Kahne et al., 2016; Shirky, 2011) while there has been little in-depth study of the influence of social and digital media on the construction of social representations and values in future citizens, as has been the case with critical digital literacy (Castellví et al., 2018; Castellví et al., 2019; Santisteban et al., 2020).

\section{CRITICAL DIGITAL LITERACY IN CITIZENSHIP EDUCATION}

In recent years, the number of papers on the concept of critical digital literacy has increased. Although the concept is recent, this research line emerged from critical literacy and new literacies, which have their origin in critical pedagogy, social studies and sociolinguistics (Castellví, 2019; Tosar, 2017). Although previous studies have addressed the impact of digital environments on literacy and the development of critical thinking, now the concept has been consolidated and we consider these processes not only have repercussions on all areas of digital communication, information and learning, but traditional ones too.

A short bibliographical review reveals that research on critical digital literacy has addressed some of the problems that education faces today, such as the power of hegemonic discourses (De Los Ríos, 2018; Golden, 2017), post-truth and fake news (Das \& Pavličcková, 2013; Sulzer, 2018), social vigilance politics (Hutchinson \& Novotny, 2017; Vang, 2013), radicalization and the production of counter-narratives (Arroyo et al., 2018; García-Ruiz \& Zorrilla, 2019; Izquierdo, 2019; McNicol, 2016), democratic participation (Yue et al., 2019), or social transformation (San-Millán \& Mazzucchelli, 2016; Watt, 2019). It is no coincidence that these topics coincide with the challenges that citizenship is facing in present times.

Our proposed approach goes along the lines of educating for a critical, participative and transformative citizenry that is capable of living in a digital world, since in our opinion this is the approach that tackles the social challenges that we have previously proposed, seeking solutions that are at the root of the problem. Indeed, we feel that critical digital literacy needs to be an essential part of citizenship education. This proposal must therefore consider democratic participation and 
social transformation in order to deal with this disaffection towards democratic institutions, but it should not neglect the development of critical thinking in order to identify the ideology beyond the lines (Gray, 1960), to revise one's own values, and to make informed moral judgments.

From the perspective of a critical and democratic citizenship, Kennedy (2019) defends the importance of considering values and the ability to make moral judgments as one of the challenges of citizenship education. This author states that "young people should be equipped with the ability to critically evaluate information, make moral decisions about it, and adopt courses of action that seek to improve the human condition" (p. 26). From social studies, especially from citizenship education research, certain desirable values have been established, such as solidarity, equality, tolerance and social justice, among others. However, it remains unclear where the discussion of values fits into the teaching of critical thinking. For some authors, critical thinking is a set of cognitive skills that do not depend on the social and cultural context (Boisvert, 2004). In contrast, the conceptualization of critical thinking from the perspective of critical literacy and critical pedagogy has always defended the impossibility of adopting neutral standpoints in the critical analysis of reality, although explicit debate of the values that can be associated to critical thinking has often been neglected (Luke, 2020).

The research we are presenting here analyzes from critical digital literacy the written narrations and reflections of high school students in Spain after reading two posts on Twitter that use false or biased information to promote undemocratic discourses concerning gender violence, homophobia and totalitarian ideologies. Finally, we compare the results with other investigations with a similar object of study to shed light on the challenges faced by education for citizenship in a digital world, to offer clues as to how it should be developed in secondary education.

\section{METHOD}

This study is part of a funded research project ${ }^{1}$ involving various Spanish universities. Here we advance part of the results obtained. The main objective was to analyze the ability of secondary school students to critically analyze the information that appears in digital and social media and assess the veracity, reliability or intentionality of information sources on controversial issues, arguing about the

\footnotetext{
${ }^{1}$ See the research project "Educación para el futuro y esperanza en la democracia. Repensar la enseñanza de las ciencias sociales en tiempos de cambio.", Funded by the Spanish Ministry of Science and Innovation (R\&D PID2019-107383RB-I00, PI: Dr. Antoni Santisteban).
} 
credibility of certain information that is disseminated in digital media and on social networks.

The sample was made up of 250 upper secondary students from different schools in Spain. The tool used in this phase of the research was an online questionnaire, which allowed us to obtain certain quantitative and qualitative data. Data was collected from a series of activities and open questions that were done individually in a total time of 45 minutes, and which were designed to explicitly encourage the students to demonstrate the extent to which they are critical readers of digital and social media, and how they build their own narratives about the social issues presented. For all questions, they were able to consult any type of source to verify the information, complete it or look for other sources that contradict it.

In this study, we analyze the narratives of students that arose from two of the activities in the questionnaire that required them to critically analyze certain tweets that reproduce news with problematic content, and which requires their assessment, interpretation and verification. In the first activity, the students had to assess and interpret an image that accompanied a tweet reporting a false story about female violence against men. In the second activity they had to assess and interpret another image that corresponded to a tweet by somebody who misrepresented reality and published information attacking the LGTBIQ (Lesbian Gay Bisexual Transgender Queer) community from the standpoint of a totalitarian ideology. To analyze whether the information obtained from this questionnaire was critical or not, we created a rubric (Table 1), based on Santisteban et al. (2020) and Wineburg et al. (2016) proposals, using three categories: beginner, emerging and expert.

Table 1. Rubric to classify the students' narratives. Source: authors

\begin{tabular}{ll}
\hline Category & \multicolumn{1}{c}{ Characteristics } \\
\hline Beginner & $\begin{array}{l}\text { They argue about the information without contrasting it. They justify the tweet } \\
\text { or share the view of the undemocratic discourse presented. }\end{array}$ \\
Emerging & $\begin{array}{l}\text { They argue about the information to the point of doubting its veracity in some } \\
\text { cases. They oppose the view of the undemocratic discourse presented. }\end{array}$ \\
Expert $\quad \begin{array}{l}\text { They argue about the information, opposing the view of the undemocratic dis- } \\
\text { course and identifying the author's underlying totalitarian ideology and his inten- } \\
\text { tion to spread these discourses against vulnerable communities. }\end{array}$ \\
\hline
\end{tabular}


At the same time, within each of the categories, we distinguished certain aspects that help to characterize the responses, to differentiate the most outstanding nuances of each one, and which focus on the ability of students to value information and make moral judgments based on democratic values.

\section{RESEARCH RESULTS}

\section{First activity}

In the first of the activities analyzed, we asked the students to critically interpret a tweet by a user who has published a fake news story (Figure 1) that tends to appear in some way or other every year in social networks. This news item hides an ideology that aims to divert attention from cases of violence against women. We analyze the students' ability to put the information in quarantine until its veracity is proven, and their capacity to do so.

Figure 1. First activity in the critical digital literacy questionnaire

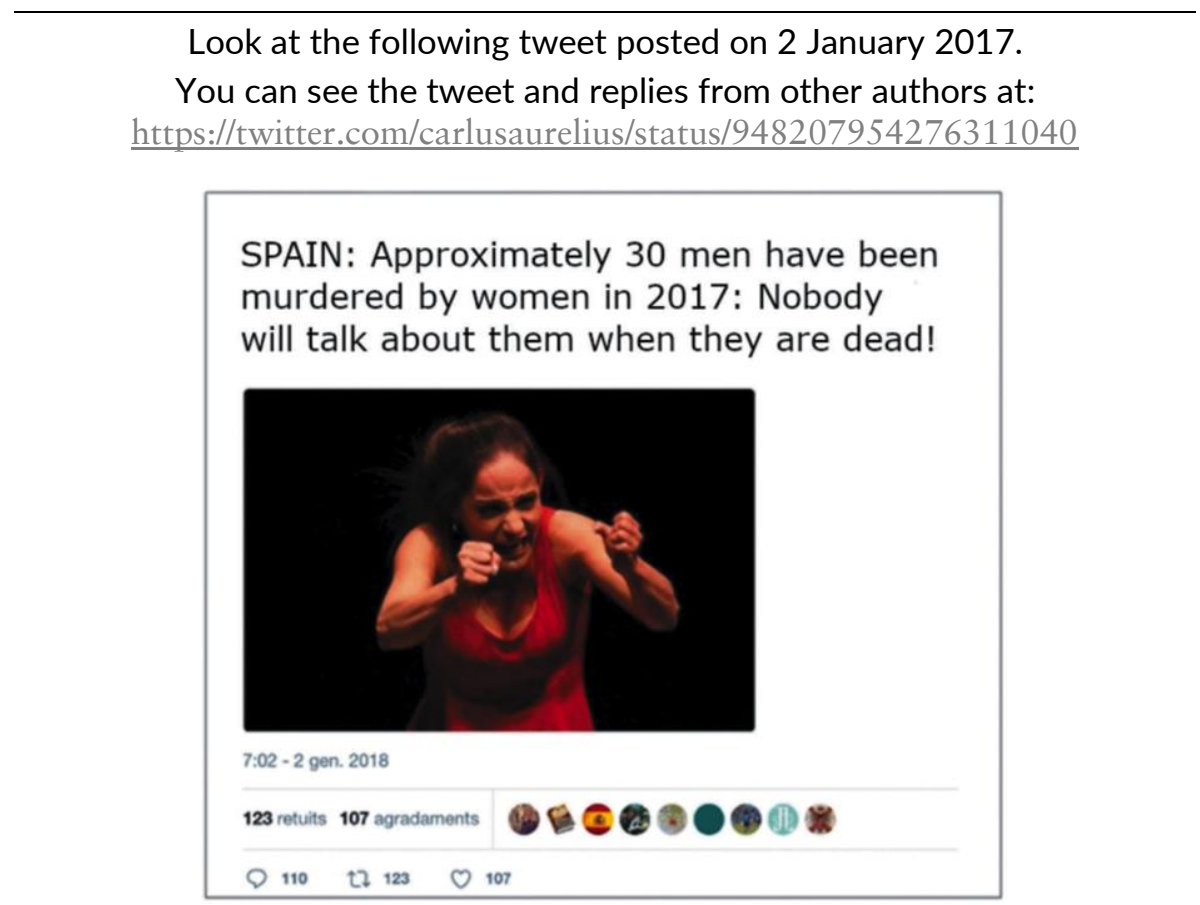

Use the internet or other digital media to check this information and tell us your opinion about this issue and the comparison made in the tweet.

The results show us that the students' narratives are mainly classed in the beginner category, since 114 of them, $45.6 \%$, do not criticize the sexist tweet (Figure 2). Alfonso (all names have been anonymized, but we maintain the gender of 
the informant) takes the same position as the author of the tweet when he makes the following statement:

1. Alfonso: It is very bad that this happens, gender violence is only broadcast in the news, in the newspapers ... when a man attacks a woman. When the opposite occurs, that is, when a woman assaults a man, nobody mentions it.

Alfonso thinks that the data provided by the author of the tweet is reliable and assumes that the reason why he has seen no news in the media about male deaths is because this information is hidden. This is the majority view within this first category, responding to 43 narratives. On the other hand, 34 narratives classified in the beginner category take a similar line to Alba's narrative:

2. Alba: I think these cases are often treated as unimportant. In actual fact, most cases like these are against women, but in my opinion, they should all be treated with the same importance.

Alba justifies the false information provided by the author of the tweet, although she acknowledges that female deaths are more numerous. However, she thinks that these cases should be treated equally in the media, as claimed in the tweet. Approximately a third of the beginner narratives allude to democratic values to support their moral judgments, which is a much higher amount than in the other categories. The value of equality is interpreted by students to mean equal treatment for everyone, as emerges from Carlos' narrative:

3. Carlos: I think we should talk about equality. In the news they only talk about how many women have been killed by men and in demonstrations "people talk about equality" when some women (more than half) are only there to speak against men, when they are supposed to be demonstrations for equality.

Figure 2: results obtained from the classification of the narratives in the first activity

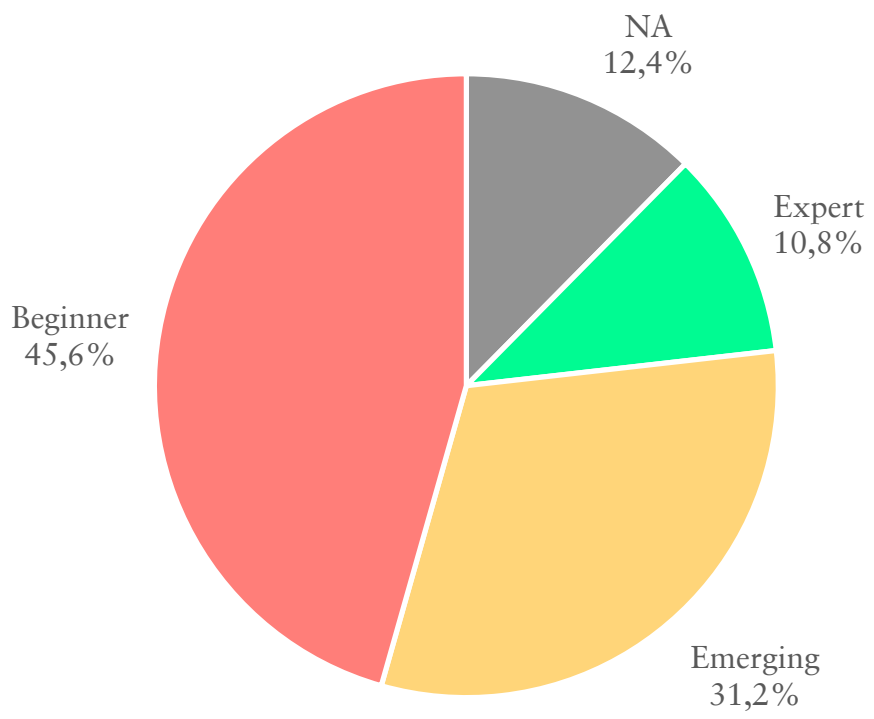


Students that write beginner narratives use arguments such as Carlos' and ignore the fact that when oppression occurs, it is equitable (and not egalitarian) treatment that leads to equal opportunities and more egalitarian societies.

We classed the stories of 78 students, $31.2 \%$, in the emerging category (Figure 2), in which the inadequate comparison between murdered men and women is highlighted, and where students strongly disagree with the author's views and, in some cases, question the veracity of the information. However, they fail to identify the author's ideology or intentionality. Nerea trusts the veracity of the information, although she totally opposes the author's view:

4. Nerea: I think that for each man that dies at the hands of a woman there are 100 women who die at the hands of men, that is why they pay more attention to women, to make us aware of what is happening.

Nerea does not think that the figures are comparable, and that the complaint made in the tweet is therefore unjustified. Such narratives are the majority within the emerging category, for 54 students have similar standpoints. Some students go further and question the information. Nil checks the information and identifies it as false:

5. Nil: I think men also die in the world but not 30 a year. In fact, I looked it up on the internet and it says that from 2008 to 2014 less than 11 men died. However, in these 7 years, for every male death from gender violence, there were seven women who died.

Nil argues that the comparison is inadequate, and he does so with contrasted data. We found 24 similar narratives to Nil's in the emerging category, and which come close to the expert level.

Finally, we only classified 27 narratives $(10.8 \%)$ in the expert category (Figure 2). These are the only ones that are truly critical of the undemocratic discourse. The students demonstrate the ability to make a moral judgment and reflect about it. Furthermore, they question the veracity of the information and identify the ideology and/or intentionality of the author of the tweet. Elia's narrative is a good example:

6. Elia: This tweet is fake news. In my opinion, the person who posted this tweet was uninformed before publishing it and I suppose he did it to imply that not only do they murder women, but that there is also gender violence against men, (which I do not deny because everyone, both women and men, can suffer from gender violence), but as it is false news, it is not valid. "No one will talk about them when they are dead" refers to the fact that now, with so many murders of women, people are trying to put a stop to the catastrophe and are speaking up for women. Feminists are giving these women a voice, but the 
tweet claims that nobody is speaking up for men when they die (but they obviously aren't because the story is FALSE).

Elia also attaches a link with information that refutes the news story. This student contrasts the information and shows that it is false, reflecting on the author's intent, determining the ideological positions involved and making a moral judgment on gender violence and the situation of oppression in which women live.

\section{Second activity}

In the second activity analyzed (Figure 3), the students had to critically interpret a tweet by a user stating his opinion about a misrepresented fact. The comparison of an LGTBIQ float with a Francoist float demonstrates a totalitarian ideology on the part of the author. The opinion disseminated in this tweet is about a controversial issue that generated numerous items on the digital media, many of which have been homophobic and sought to manipulate the reality, so the sources need to be contrasted to reveal that this group was doing nothing more than parade in Christmas costumes.

Figure 3. Second activity of the critical digital literacy questionnaire

Look at the following tweet posted on $5^{\text {th }}$ January 2018 about the presence of a LGBTQ float in the Three Wise Men parade in Madrid's Vallecas neighborhood.

You can see the tweet and its replies from other authors at: http://twitter.com/juanjesu90/status/948547529708326912

If there can be gay floats then pro-Franco floats should be allowed. So, you are the intolerant one.

\#CavalcadeARV

$5: 32-3$ ene. 2018

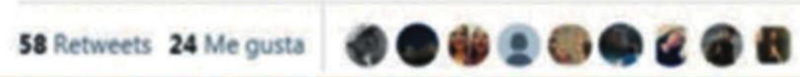

Use the internet or other digital media to check this information and tell us your opinion about this issue and the comparison made in the tweet.

The results are in line with those of the previous activity, although they are slightly different. A lower percentage are classified as beginners, 46 students, $18.4 \%$ of the total (Figure 4), as they justify the allusion to the possibility of a 
Francoist float and thus present uncritical and favorable narratives with regard to the undemocratic discourse. The narratives we classify in this category share similar characteristics, with students like Pedro agreeing with the Twitter user and considering that a gay float is not suitable for a Christmas parade:

7. Pedro: It is not a matter of intolerance, it is a matter of common sense. The parade is supposed to be a tradition, there is no reason to mix political or ethnic themes with this type of parade or tradition. It stains the image of the parade.

Pedro appeals to tradition to justify his standpoint, stressing that this is not intolerance but common sense. Twenty-nine of the narratives classified in the beginner category demonstrate a favorable and uncritical position regarding the information presented. Others justify the presence of a Francoist float in pursuit of free speech. This is the case of Laura's story:

8. Laura: I think this tweet is right since some people are allowed to take part in a demonstration to present their sexual orientation but others are not allowed to do likewise for their political ideology. That is very unfair because they all have the same freedom of expression.

We found 17 narratives like Laura's among the narratives classified as beginners. They are uncritical of the information presented and defend the display of fascist symbols in public spaces, arguing more or less explicitly that it is a matter of freedom of opinion.

Figure 4. results obtained from the classification of the narratives in the second activity

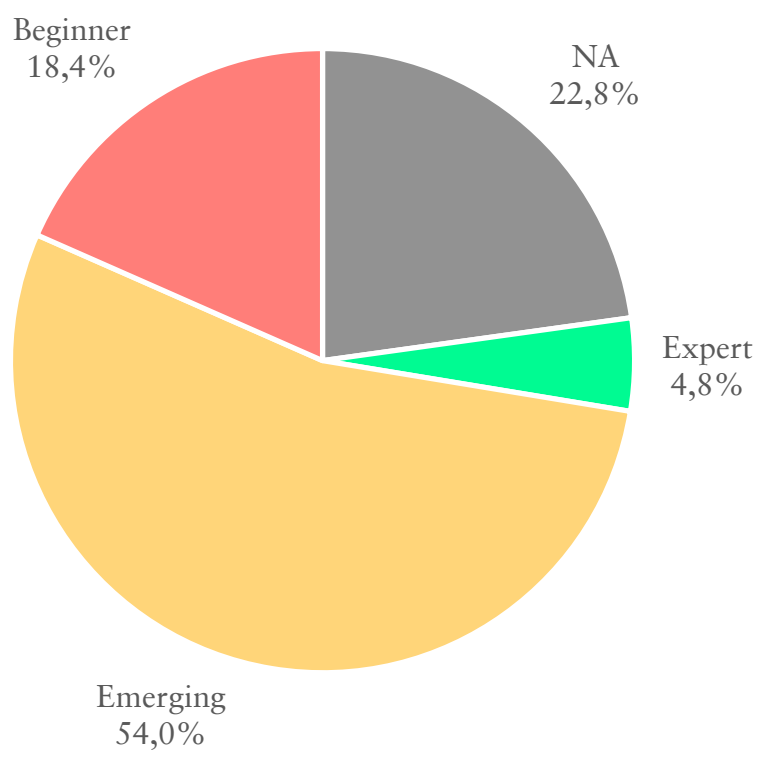


We classify most of the narratives in the emerging category. One hundred and thirty-five students, 54\% (Figure 4), do not think that a gay float can be compared with a Francoist float, and oppose the expressed complaint. However, an analysis of the stories does not allow us to affirm that they are totally critical, since they are not able to identify the author of the tweet's ideology and intent. We classify Carla's story in this category:

9. Carla: I think they are two very different things because he is mixing homosexuality with politics. Homosexuality should not be frowned upon because it is normal that instead of being boy-girl, they are boy-boy, or girl-girl. They don't hurt anyone. While politics does, due to corruption, crisis...

Some students like Carla argue that the inappropriate comparison is not the one between sexual orientation and undemocratic ideology, but that the issues are not comparable because one is about politics. These types of narratives also point out that one cannot compare sexual orientations with ideologies. In both cases, negative connotations are attributed to politics and ideology, regardless of whether democratic positions are defended from these areas. However, most of the authors of emerging narratives make simplistic reflections determining that Francoist floats do harm and gay floats do not. Furthermore, they attribute the fact that a person publishes undemocratic speeches on the Internet to disinformation or stupidity, and not to the defense of totalitarian ideologies. Sergio says:

10. Sergio: I think this tweet is silly. It is evident that gay people have suffered a lot in history and deserve to have something to celebrate.

It is also in the emerging category where the number of narratives that evoke democratic values is greater. Students highlight such values as equality, freedom and tolerance, and use them to justify their views of the problem. Nadia argues the following:

11. Nadia: The float that represents homosexuality does not affect anyone since it is freedom of expression and a form of revolution, while the Francoist float comes from a way of thinking that has been stagnant for many years since it dates from an authoritarian and retrograde regime.

The narratives classified in the expert category show that these students have been able to critically reflect on the information and have identified the undemocratic discourse hidden between the lines. Such narratives are in the minority, since we can only classify 12 of these, $4.8 \%$ (figure 2 ). Rosa's text is an example: 
12. Rosa: In my opinion you cannot compare one thing with the other. This comment is out of place. It seems that whoever wrote this tweet is defending the idea that being homosexual is something bad. Therefore, it does not defend social freedom.

Rosa considers that the author's intention is to undermine the gay community and a sexual orientation. Maria's narrative shows that she has identified the author's homophobic and totalitarian ideology:

13. Maria: He is a homophobe, since if he is complaining about a float made by the LGTBQ+ community, then that shows lack of respect. And what's more, if the author of the tweet says that there should be a Francoist float, that really is the last straw, because he is supporting a group of homophobic, sexist fascists.

The stories in this category have similar characteristics, however it is noteworthy that very few students question the information presented in the tweet, and none of them have been able to identify that the information it presents is biased, since the LGTBQ+ float was not a gay pride float (as implied), for its members were wearing Christmas costumes.

\section{CONCLUSION}

The results show that the majority of the students are not able to make a truly critical reflection on the information presented. These data are consistent with the results obtained in similar investigations carried out with primary school (Castellví, 2019; Tosar, 2018) and undergraduate students (Castellví et al., 2018; Castellví et al., 2019; Massip et al., 2019; Santisteban et al., 2020; Wineburg et al., 2016). In their stories, the students evoke democratic values such as equality, tolerance and freedom. However, they do not do so from knowledge and reflection on these values, but rather they use them as powerful elements to support their views, even though they are far removed from the meaning of these values in a democratic context. This highlights the way that undemocratic discourses condition students' standpoints on social issues, but they are also used to support previous standpoints through their acceptance or rejection.

Decision-making is a complex process that involves evaluating and making moral judgments based on partial information (Delli Carpini, 2009). These decisions are not made from purely rational reflections, but include multiple elements such as emotions, prior knowledge, values and beliefs (Castellví et al., 2019; Delli Carpini, 2009; Kennedy et al., 2013). Our results show that most students made moral judgments only based on these elements, not combining them with deliberative reflections that would imply, for example, the consultation of multiple sources and the contrasting of the information. Also, these moral judgments were often 
biased, probably due to the lack of reflection at school (and at other socialization spaces) about values and emotions as inherent part of the development of their critical thought.

The fact that multiple elements are involved in the production of discourses on controversial issues and that the results obtained in the two activities, although similar, are not the same, shows that the ability to make critical reflections and moral judgments based on democratic values depends partially on the context. This condition is decisive since digital environments foster the creation of information bubbles, that is, the creation of informational contexts in which we see, hear and listen to information that is assimilated to our tastes, opinions and ideology, and where there is no place for dissident voices (Turkle, 2015).

Education for citizenship has been questioned by authors like Biesta (2011), who considers that we should instead speak of learning democracy. This shift implies that we cannot attribute the blame for the results obtained in this and other similar investigations to individual students, but instead that it is a systemic dysfunction that goes beyond students and formal education. This author maintains that education for citizenship should depart from reflection on and construction of the idea of citizenship and the values associated with it. Critical digital literacy, which includes work based on relevant social issues and democratic education for participation and social transformation, may be a relevant path for this purpose.

\section{ACKNOWLEDGEMENTS}

This study was conducted within the R\&D PID2019-107383RB-I00 project subsidized by the Spanish Ministry of Science and Innovation.

\section{REFERENCES}

Andreotti, V. (2006). Soft versus critical global citizenship education. Policy \& Practice-A Development, 3, 40-51.

Arroyo, A. Ballbé, M., Canals, R., García-Ruíz, C.R., López, M., Oller. M., \& Santisteban, A. (2018). El discurso del odio: una investigación en la formación inicial. In E. López-Torres, C. R. García-Ruíz \& M. Sánchez-Agustí (Eds.), Buscando formas enseñar: investigar para innovar en didáctica de las ciencias sociales (pp. 413-424). Universidad de Valladolid/AUPDCS.

Biesta, G. J. J. (2011). From teaching citizenship to learning democracy. In G. J. J Biesta (Ed.), Learning democracy in school and society. Education, lifelong learning, and the politics of citizenship (pp. 5-16). Sense Publishers.

Blikstad-Balas, M. (2015). "You get what you need": A study of students' attitudes towards using Wikipedia when doing school assignments. Scandinavian Journal of Educational Research, 60(6), 1-15. https://doi.org/10.1080/00313831.2015.1066428 
Boisvert, J. (2004). La formación del pensamiento crítico. Fondo de Cultura Económica.

Castellví, J. (2019). Literacitat crítica digital en els estudis socials. Estudis de cas en educació primària [ $\mathrm{PhD}$ thesis]. Universitat Autònoma de Barcelona.

Castellví, J., Díez, M. C., Gil, F., González-Valencia, G., Jiménez, M. D., Tosar, B., Dunia, E., Yuste, M., \& Santisteban, A. (2018). Ante la mentira: educación en literacidad crítica y acción social. In M.A. Jara, G. Funes, F. Ertola, \& M.C. Nin (Eds.), Los aportes de la didáctica de las ciencias sociales, de la história y de la geografía a la formación de la ciudadanía de los contextos iberoamericanos (pp. 645-653). Universidad Nacional del Comahue.

Castellví, J., Massip, M., \& Pagès, J. (2019). Emociones y pensamiento crítico en la era digital: un estudio con alumnado de formación inicial. Revista de Investigación en Didáctica de las Ciencias Sociales, 5, 23-41.

Das, R., \& Pavlícková, T. (2014). Is there an author behind this text? A literary aesthetic driven approach to interactive media. New Media \& Society, 16(3), 381-397.

https://doi.org/10.1177/1461444813481296

Davies, I. (2006). Global citizenship: abstraction or framework for action? Educational Review, 58(1), 5-25. https://doi.org/10.1080/00131910500352523

De Los Ríos, C. V. (2018). Bilingual vine making: Problematizing oppressive discourses in a secondary Chicanx/Latinx studies course. Learning, Media and Technology, 43(4), 359-373. https://doi.org/10.1080/17439884.2018.1498350

Debord, G. (2015). La sociedad del espectáculo. Pre-Textos.

Delli Carpini, M. X. (2009). The psichology of civic learning. In E. Borgida, C.M Federico \& J.L. Sullivan (Eds.), The politcal psichology of democratic citizenship (pp. 23-51). Oxford University Press.

Eco, U. (1998). Cinco escritos morales. Lumen.

Estellés, M., \& Fischman, G. (2020). Who needs global citizenship education? A review of the literature on teacher education. Journal of Teacher Education, 72(2) 1-14. https://doi.org/10.1177/0022487120920254

Freire, P. \& Macedo, D. (2004). Literacy: Reading the word and the world. London: Routledge.

García-Ruiz, C. R., \& Zorrilla, J. L. (2019). Educar para la ciudadanía frente a discursos de odio desde la prensa digital. Una experiencia en formación inicial del profesorado de educación secundaria. In M. J. Hortas, A. Dias, \& N. de Alba (Eds.), Enseñar y aprender didáctica de las ciencias sociales: la formación del profesorado desde una perspectiva sociocrítica (pp. 659-666). AUPDCS - ESE/PL.

Golden, N.A. (2018). Critical digital literacies across scales and beneath the screen. Educational Media International, 54(4), 373-387. https://doi.org/10.1080/09523987.2017.1391523

González-Valencia, G., Ballbé, M., \& Ortega-Sánchez, D. (2020). Global citizenship and analysis of social facts: Results of a study with pre-service teachers. Social Sciences, 9(5), 65. https://doi.org/10.3390/socsci9050065

Gray, W. S. (1960). The major aspects of reading. In J. Robinson (Ed.), Sequential development of reading abilities (pp. 8-24). Chicago University Press.

Havas Group (2011). Millenials: The challenger generation. Prosumer Report, 11. https:/www.yumpu.com/en/document/read/13340608/millennials-the-challenger-generation-prosumer-reports

Hutchinson, L., \& Novotny, M. (2018). Teaching a critical digital literacy of wearables: A feminist surveillance as care pedagogy. Computers and Composition, 50, 105-120. 
Izquierdo, A. (2019). Contrarelats de l'odi a l'ensenyament i l'aprenentatge de les ciències socials. Una recerca interpretativa i crítica a l'Educació Secundària [PhD thesis]. Universitat Autònoma de Barcelona.

Kahne, J., Hodgin, E., \& Eidman-Aadahl, E. (2016). Redesigning Civic Education for the Digital Age: Participatory Politics and the Pursuit of Democratic Engagement. Theory \& Research in Social Education, 44(1), 1-35. https://doi.org/10.1080/00933104.2015.1132646

Kellner, D. (2005). Media spectacle and the crisis of democracy. Terrorism, war \& election battles. Paradigm Publishers.

Kennedy, K. J. (2019). Civic and citizenship education in volatile times. Preparing students for citizenship in the 21st century. Springer.

Kennedy, K. J., Kuang, X., \& Chow, J. K. F. (2013). Exploring Asian students' citizenship values and their relationship to civic knowledge and school participation. Educational Psychology: An International Journal of Experimental Educational Psychology, 33(3), 240-261. https://doi.org/10.1080/01443410.2013.775003

Luke, A. (2020). Regrounding critical literacy. In D. E. Alvermann, N. J. Unrau, M. Sailors, \& R. B. Ruddell (Eds.), Theoretical models and processes of literacy (pp. 349-362). Routledge.

Massip, M., Castellví, J., \& González-Valencia, G. A. (2019). Entre la emoción y el pensamiento crítico: un estudio con profesorado de ciencias sociales en formación. In E. J. Díez \& J.R Rodríguez (Eds.), Educación para el bien común. Hacia una práctica crítica, inclusiva y comprometida socialmente (pp. 535-543). Octaedro.

McNicol, S. (2016). Responding to concerns about online radicalization in the UK schools through a radicalization critical digital literacy approach. Computers in the Schools, 33(4), 227-238.

Oxley, L., \& Morris, P. (2013). Global citizenship: A typology for distinguishing its multiple conceptions. British Journal of Educational Studies, 61(3), 301-325.

Ross, E. W. (2013). Spectacle, critical pedagogy and critical social studies education. In J. J. DíazMatarranz, A. Santisteban \& A. Cascajero (Eds.), Medios de comunicación y pensamiento crítico. Nuevas formas de interacción social (pp. 19-43). Editorial Universidad de Alcalá.

San-Millán, N., \& Mazzucchelli, P. C. (2016). De la reflexión a la acción. Relato de la experiencia RoadsMOOC, como viaje educomunicativo de transformación personal y social. Mediterránea de Comunicación, 7(2), 81-97.

Santisteban, A., Díez-Bedmar, M. C., \& Castellví, J. (2020). Critical digital literacy of future teachers in the Twitter age (La alfabetización crítica digital del futuro profesorado en tiempos de Twitter). Culture and Education, 32(2), 185-212. https://doi.org/10.1080/11356405.2020.1741875

Schulz, W., Ainley, J., Fraillon, J., Losito, B., \& Agrusti, G. (2016). IEA international civic and citizenship education study 2016: Assessment framework. International Association for the Evaluation of Educational Achievement (IEA). https://doi.org/10.1007/978-3-31939357-5

Shirky, C. (2011). The political power of social media: Technology, the public sphere, and political change. Council on Foreign Relations, 90(1), 28-41.

Sulzer, M. A. (2018). (Re)conceptualizing digital literacies before and after the election of Trump. English Teaching: Practice \& Critique, 17(2), 58-71. https://doi.org/10.1108/ETPC-062017-0098

Tosar, B. (2017). Llegir la paraula i el món. Literacitat crítica en els estudis socials a l'educació primària [PhD thesis]. Universitat Autònoma de Barcelona. 
Tosar, B. (2018). Literacidad crítica y enseñanza de las ciencias sociales en primaria: "Profe, las bolsas de plástico no son medusas". Revista de Investigación en Didáctica de las Ciencias Sociales, 2, 4-19.

Turkle, S. (2015). Reclaiming conversation: The power of talk in a digital age. Penguin.

Vang, K.J. (2013). Ethics of Google's knowledge graph: some considerations. Journal of Information, Communication and Ethics in Society, 11(4), 245 - 260.

Watt, D. (2019). Video production in elementary teacher education as a critical digital literacy practice. Media and Communication, 7(2), 82-99.

Westheimer, J., \& Kahne, J. (2004). What kind of citizen? The politics of educating for democracy. American Educational Research Journal, 41, 237-269. https://doi.org/10.3102/00028312041002237

Wineburg, S., McGrew, S., Breakstone, J., \& Ortega, T. (2016). Evaluating information: The cornerstone of civic online reasoning. Stanford Digital Repository.

Yue, A., Nekmat, E., \& Beta, A. R. (2019). Digital literacy through digital citizenship: Online civic participation and public opinion evaluation of youth minorities in Southeast Asia. Media and Comunication, 7(2), 100-114.

\section{JORDI CASTELLVÍ MATA}

Jordi Castellví has a degree in History and Primary Education, and a PhD. in Education (2019). His interests are research methodologies, global citizenship education, the phenomenon of populism and the development of critical thinking in digital contexts. Castellví had a scholarship from the Spanish Ministry of Economy and Competitiveness as part of the R\&D EDU2016-80145-P project at the Universitat Autònoma de Barcelona, where he has worked as research a fellow of Social Studies Education. He is currently a lecturer at the UNIR (Universidad Internacional de la Rioja).

jordi.castellvimata@unir.net https://orcid.org/0000-0002-6487-5477

\section{BREOGÁN TOSAR BACARIZO}

Breogán Tosar has a PhD. in Education from the Autonomous University of Barcelona. His thesis Read the word and the world. Critical Literacy in Social Studies in Primary Education received the $\mathrm{PhD}$. Special Prize Award in 2018. Tosar is part-time lecturer of Social Studies Education in the same university, and advisor in language, interculturality and social cohesion in the Department of Education of the Catalan regional government.

breogan.tosar@uab.cat https://orcid.org/0000-0002-1885-6638

\section{ANTONI SANTISTEBAN FERNÁNDEZ}

Antoni Santisteban Fernández is an Associate Professor at the Universitat Autònoma de Barcelona (UAB). He has a PhD. in Social Science Education. He is the Director of the Department of Language, Literature and Social Science Education. He has published more than 200 articles, book chapters and books. He has been on the national and international committees of scientific journals and agencies of university quality. He is the coordinator of the GREDICS consolidated research group. His research interests are the teaching and learning of critical social science and citizenship education. 


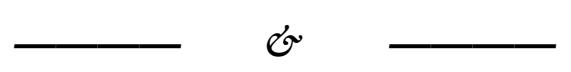

Castellví Mata, J., Tosar Bacarizo, B. \& Santisteban Fernández, A. (2021). Young people confronting the challenge of reading and interpreting a digital world. Bellaterra Journal of Teaching o Learning Language \& Literature, 14(2), e905. https://doi.org/10.5565/rev/jtl3.905

Rebut / Recibido / Received / Reçu: 10-06-2020

Acceptat / Aceptado / Accepted / Accepté: 10-07-2020 